\title{
MICROPHYTOPLANKTON OF THE MARAPANIM ESTUARY (PARÁ, NORTHERN BRAZIL)
}

\author{
Daniela dos Santos SANTANA ${ }^{1}$ \\ Rosildo dos Santos PAIVA ${ }^{1}$ \\ Luci Cajueiro Carneiro PEREIRA ${ }^{2}$ \\ Rauquírio Marinho da COSTA ${ }^{2 *}$
}

\begin{tabular}{|l|}
\hline Recebido: $01 / 04 / 10$ \\
\hline Aceito: $01 / 06 / 10$
\end{tabular}

The present work was carried out to determine the composition and ecology of the microphytoplankton of the Marapanim River estuary (Amazon region, Pará-Brazil). Samples were collected quarterly during a period of one year from November/2002 to September/2003, in the flood and ebb neap tide at six different stations distributed along the estuary. Analyses were developed with samples collected through subsurface horizontal plankton net (64 $\mu \mathrm{m}$ mesh size) hauls. The microphytoplanktonic assemblages were represented by 180 taxa from which 18 species were new occurrences for Pará state. Tidal currents, salinity and sediment resuspension processes probably contributed to the presence of tychoplanktonic (benthic and epiphytes), neritic and planktonic oceanic species.

KEY WORDS: Phytoplankton, estuary, Amazon region.

\section{Microfitoplâncton do Estuário do Marapanim (Pará, Norte do Brasil) RESUMO}

O presente trabalho visou o estudo da composição florística e ecologia do microfitoplâncton do Estuário do Rio Marapanim (Região Amazônica, Pará - Brazil) durante o período de novembro/2002 a setembro/2003, em maré de quadratura de lua minguante. As amostras foram coletadas em seis estações distribuídas ao longo do estuário durante as condições de maré enchente e vazante por intermédio de arrastos horizontais realizados na subsuperfície através da utilização de redes de plâncton com abertura de malha de $64 \mu \mathrm{m}$. O microfitoplâncton esteve representado por 180 táxons, sendo relatadas 18 novas ocorrências para o estado do Pará. As correntes de marés, a salinidade e os processos de ressuspensão de sedimentos, possivelmente, contribuíram para o registro de um grande número de espécies ticoplanctônicas (bênticas e epífitas), neríticas e oceânicas planctônicas na área em estudo.

PALAVRAS-CHAVE: Fitoplâncton, estuário, região amazônica.

\section{INTRODUCTION}

Estuaries are environments characterized by a great variety of particles with dimensions and composition equally variable presenting a complex fluidic circulation pattern and are considered one of the most productive tropical ecosystems worldwide (Kremer et al., 1994). These ecosystems are used as nursing grounds for a wide range of coastal nektonic species showing a high floristic and faunistic diversity of unchallenged value (Krumme \& Liang, 2004).

Studies about the plankton communities in this kind of ecosystem as well as their interaction with different physical and chemical factors are very important to the better understanding of nutritional, productive and energy flux relationship processes among

Author for correspondence. ${ }^{1}$ Universidade Federal do Pará. Campus Universitário do Guamá. Departamento de Biologia - (CCB/ UFPA).

${ }^{2}$ Universidade Federal do Pará. Campus Universitário de Bragança - (CABRA/UFPA). Alameda Leandro Ribiro s/n, Aldeia, Bragança, Pará. Brasil.

E-mail: raucosta@ufpa.br 
different organisms that live in these zones. On the other hand, information about the planktonic biomass could subsidize fish stock estimations in adjacent coastal zones which depend on the reproductive success and on the larval development that take place in the estuaries (Espírito Santo \& Isaac ,1999; Xie \& Yang, 2000).

The phytoplankton is considered one of the most important groups among organisms that live in the estuarine zones because they constitute the base of coastal aquatic food webs and are represented by primary producers whose development depends on their permanence in the photic zone (Brandini et al., 1997).

Although the north region of Brazil is one of the priority areas for the recognition and conservation of the biodiversity of coastal ecosystems in the world little is known about the local phytoplanktonic communities (Melo et al., 2006; Sousa et al., 2008; 2009). Studies concerning the knowledge of the biotic and abiotic components of the estuarine zones of the Pará state could contribute to the understanding of the local planktonic community structure clarifying trophodynamic relationship aspects and offering data that permit the evaluation of fish stocks of their estuaries.

The main aim of this study was to determine the composition of the microphytoplankton in the Marapanim estuary showing species occurrence and giving ecological data about the identified taxa contributing to the knowledge of the estuarine communities of the Amazon region.

\section{STUDY AREA}

Brazil has $8,500 \mathrm{~km}$ of coastline (Joyeux et al., 2004) with the second largest continuous mangrove area on earth (Kjerfve et al., 1997). The coast of Pará represents 7\% of the state territory and holds almost $50 \%$ of the state population (Glaser \& Diele, 2004).

The region is dominated by a humid tropical climate and a marked seasonality with most rainfall between January and June and mean annual precipitation of 2,500-3,000 mm (SUDAM, 1994). Mean air temperature is $27^{\circ} \mathrm{C}$ and relative humidity presents annual average values oscillating from 80 to $85 \%$, directly associated to the pluviometric precipitation regime (Martorano et al., 1993).

The Marapanim estuary is situated on the northeastern coast of Pará state, within a coastal Amazon sector constituted by a littoral submersion of Pará and Maranhão states located southeastern from the mouth of the Amazon River and limited by the coordinates: 00032'30"S / 00052'30"S and 47028'45"W / 47045'00"W (Berrêdo et al., 2002 in Santana, 2004). According to Silva et al. (2009), this estuary is characterized by an embayed coastline sustained by Neogene and quaternary deposits of the Barreiras formation and post-Barreiras sediments, respectively.

The estuary presents funnel shape morphology with a high wide/depth relationship and a gradually width decrease towards the river (Silva \& Mendes, 2001). It is characterized by semidiurnal macrotides with total heights of $4 \mathrm{~m}$, local combined with the action of the waves. Tide currents penetrate $62 \mathrm{~km}$ inside the estuary during the dry period and $42 \mathrm{~km}$ in the rainy period. The vertical salinity gradient is discrete as a consequence of water mixtures and the action of tide currents and horizontal gradient is strongly marked with the highest salinities nearest the coast (Berrêdo et al., 2002).

The pioneer vegetation, considered the first phase of the evolutive stage in the ecologic region, could be subdivided into other vegetable groups such as mangrove, salt marsh and grassland. The embraced area of the mangroves of the Marapanim estuary is about $130 \mathrm{~km}^{2}$ and the principal arboreal species in these areas are: Rhizophora mangle, Avicennia germinans and Laguncularia racemosa (Costa Neto et al., 2000). In zones of accretion Spartina brasiliensis could be found occupying the pioneer position in the mudsiltic plain.

\section{MATERIAL AND METHODS}

Samples were carried out in November/2002, March/2003, July/2003 and September/2003, during neap tides in the flood and ebb tides. Samplings were developed in four different stations distributed along the Marapanim estuary (1, 2, 3 and 4), one station 
in the Cuiarana River (5) and one station in Araticum-Mirim creek (6). These last two are considered tide creeks of the Marapanim estuary.

Samples collected for the qualitative analysis were obtained through subsurface horizontal plankton net $(64 \mu \mathrm{m}$ mesh size) hauls carried out during a period of three minutes. Samples were fixed with neutral formaldehyde at $4 \%$ and transported to the laboratory.

The identification of microphytoplankton taxa were developed in the laboratory and organisms were identified until the low taxonomical possible level.

For the identification of the sampled material the works of Péragallo \& Péragallo (1897-1908), Frenguelli (1928), Cupp (1943), Cleve-Euler (1951, 1952, 1953), Husted (1930, 1959, 1961/1966), Desikachary (1959), Hendey (1964), Wood (1968), Bourrely (1972), Dodge (1982), Balech (1988), Silva-Cunha \& Eskinazi-Leça (1990), Sournia (1986) and Tomas (1997) were used. Taxonomic position follows Desikachary (1959) for Cyanophyta, Round et al. (1990) for Bacillariophyta, Balech (1988) for Dinophyta and Bourrely (1972) for Chlorophyta.

For the ecological characterization of the registered taxa data obtained from MoreiraFilho (1961), Eskinazi- Leça (1967/69), Moreira-Filho et al. (1968, 1985, 1990, 1999), Eskinazi- Leça \& Koening (1985/86), Sardeiro \& Eskinazi- Leça (1985), Mosimann (1985, 1988), Gomes (1989) and Ribeiro (1996) were used.

\section{RESULTS AND DISCUSSION}

The microphytoplankton of the Marapanim estuary was represented by 180 taxa (Table 1 ) distributed in five divisions. The Cyanophyta represented $2.8 \%$ of the identified organisms and was constituted by 5 taxa distributed in one class, two orders, three families and three genera. The Dinophyta occupied the third place in terms of qualitative composition presenting $6.6 \%$ of the registered taxa. This division was composed by 12 taxa distributed in one class, two orders, four families and 5 genera. The most represented genera in terms of number of species were Ceratium (6 spp.) and Protoperidinium ( $3 \mathrm{spp}$. .). The Dictyophyta was the least represented division presenting only $0.6 \%$ of the identified taxa framed in one class, one order, one family and one species, Dictyocha fibula. The Bacillariophyta was the most represented division and it was constituted by one hundred forty taxa (77.3\% of the observed organisms) distributed in three classes, nine sub classes, twenty two orders, thirty eight families and sixty four genera. Genera with the higher number of species were: Chaetoceros (23 spp.), Coscinodiscus (7 spp.) and Nitzschia (7 spp.). Chlorophyta was represented by twenty three taxa ( $12.7 \%$ of the registered taxa) distributed in two classes, three orders, four families and thirteen genera. The most represented genera were Closterium (4 spp.), Xanthidium (4 spp.) and Staurastrum (3 spp.).

The predominance of diatoms has been reported for the majority of the tropical and subtropical estuaries and it used to occur when the marine flux was more remarkable (Patrick, 1967). In the estuaries of Pernambuco state (northeast Brazil) diatoms contributed with more than $80 \%$ of the microphytoplanktonic identified species (Travassos, 1991; Silva - Cunha et al., 1993; Flores - Montes, 1996 and Lacerda et al., 2004). In the Amazon littoral, recent studies showed similar results, with diatoms representing between $84.4 \%$ (Sousa et al., 2009) and 88.5\% (Sousa et al., 2008) of the identified species.

Although the Chlorophyta occupied second place in number of species $(12.7 \%)$, the organisms of this division were observed only in the rainy season (March/2003), indeed in the stations situated at the mouth of the estuary. For this group, a similar number of species were observed by Travassos (1991) in the Capibaribe estuary (Pernambuco, northeast of Brazil) and in the harbour area of Suape, Pernambuco (Koening, 1997). In the Marapanim estuary, as could be seen in other Brazilian northeast estuaries, the presence of Chlorophyta was related to the lowest salinity values. Smayda (1983) also observed the presence of Chlorophyta during the predominance of limnetic flux. 
Table1. Microphytoplankton composition in Marapanim River estuary (Pará, Northern Brazil) during the flood and ebb tide (November/2002 to September/2003).

\begin{tabular}{|c|c|c|}
\hline Division Cyanophyta & Family Hyalodiscaceae & Cymatosira belgica Grunow \\
\hline Class Cyanophyceae & Hyalodiscus laevis Ehrenberg & Cymatosira lorenziana Grunow \\
\hline Order Chroococcales & Podosira hormoides (Mont.) Kützing & SubClass Rhizosoleniophycidae \\
\hline Family Chroococcaceae & Family Paraliaceae & Order Rhizosoleniales \\
\hline Microcystis sp. & Paralia sulcata (Ehrenberg) Cleve & Family Rhizosoleniaceae \\
\hline Order Nostocales & Order Coscinodiscales & Dactyliosolen fragilissimus (Bergon) Hasle \\
\hline Family Oscillatoriaceae & Family Coscinodiscaceae & Guinardia delicatula (Cleve) Hasle \\
\hline Oscillatoria sp.1 & Coscinodiscus apiculatus Ehrenberg & Guinardia flaccida (Castr.) Peragallo \\
\hline Oscillatoria sp.2 & Coscinodiscus centralis Ehrenberg & $\begin{array}{l}\text { Pseudosolenia calcar-avis } \quad \text { (Schultze) } \\
\text { Sündström }\end{array}$ \\
\hline Oscillatoria sp.3 & Coscinodiscus concinnus W. Smith & $\begin{array}{l}\text { Rhizosolenia hebetata f. semispina } \\
\text { (Hensen) Gran }\end{array}$ \\
\hline Family Nostocaceae & $\begin{array}{l}\text { Coscinodiscus jonesianus } \quad \text { (Greville) } \\
\text { Ostenfeld }\end{array}$ & Rhizosolenia imbricata Brightwell \\
\hline Anabaena sp. & Coscinodiscus oculus-iridis Ehrenberg & Rhizosolenia longiseta Zach. \\
\hline Division Dinophyta & Coscinodiscus perforatus Ehrenberg & SubClass Chaetocerophycidae \\
\hline Class Dinophyceae & Coscinodiscus rothii (Ehrenberg) Grunow & Order Chaetocerales \\
\hline Order Gymnodiniales & Palmeria hardmaniana Greville & Family Chaetoceraceae \\
\hline Family Gymnodiniaceae & Family Hemidiscaceae & Chaetoceros affinis Lauder \\
\hline Gymnodinium splendens Lebour & Actinocyclus octonarius Ehrenberg & Chaetoceros atlanticus Cleve \\
\hline Order Peridiniales & Family Heliopeltaceae & Chaetoceros borealis (Bailey) Smithson \\
\hline Family Peridiniaceae & $\begin{array}{l}\text { Actinoptychus senarius } \quad \text { (Ehrenberg) } \\
\text { Ehrenberg }\end{array}$ & Chaetoceros brevis Schütt \\
\hline Diplopsalis sp. & Actinoptychus splendens (Shabd.) Ralfs & Chaetoceros curvisetus Cleve \\
\hline Protoperidinium depressum (Bailey) Balech & $\begin{array}{l}\text { Actinoptychus trilingulatus (Brightwell) } \\
\text { Ralfs }\end{array}$ & Chaetoceros contrictus Gran \\
\hline Protoperidinium leonis (Pavillard) Balech & Polymyxus coronalis L. W. Bailey & Chaetoceros decipiens Cleve \\
\hline Protoperidinium steinii (Jorgensen) Balech & Order Asterolamprales & Chaetoceros densus Cleve \\
\hline Family Gonyaulaceae & Family Asterolampraceae & Chaetoceros diadema (Ehrenberg) Gran \\
\hline Lingulodinium polyedrum (Stein) Dodge & Asterolampra marylandica Ehrenberg & Chaetoceros didymus Ehrenberg \\
\hline Family Ceratiaceae & SubClass Biddulphicidae & Chaetoceros distans Cleve \\
\hline Ceratium candelabrum (Ehrenberg) Stein & Order Triceratiales & Chaetoceros eibenii Grunow \\
\hline Ceratium extensum (Gourret) Cleve & Family Triceratiaceae & Chaetoceros furcellatus Bailey \\
\hline $\begin{array}{l}\text { Ceratium furca (Ehrenberg) Claparede \& } \\
\text { Lachmann }\end{array}$ & Cerataulus smithii Ralfs & Chaetoceros gracilis Schütt \\
\hline Ceratium fusus (Ehrenberg) Dujardin & Cerataulus turgidus Ehrenberg & Chaetoceros laciniosus Schütt \\
\hline Ceratium lineatum (Ehrenberg) Cleve & Odontella aurita (Lyngbye) C. A. Agardh & Chaetoceros lauderi Ralfs \\
\hline Ceratium teres Kofoid & Odontella mobiliensis (Bailey) Grunow & Chaetoceros lorenzianus Grunow \\
\hline Division Dictyochophyta & Odontella regia (Schultze) Ostenfeld & Chaetoceros mitra (Bailey) Cleve \\
\hline Class Dictyochophyceae & Odontella rhombus (Ehrenberg) Kützing & Chaetoceros peruvianus Brightwell \\
\hline Order Dictyochales & Odontella sinensis (Greville) Grunow & Division Bacillariophyta \\
\hline Family Dictyochaceae & Triceratium favus Ehrenberg & Class Coscinodiscophyceae \\
\hline Dictyocha fibula Ehrenberg & Triceratium favus f. quadrata Grunow & SubClass Chaetocerophycidae \\
\hline Division Bacillariophyta & Order Biddulphiales & Order Chaetocerales \\
\hline Class Coscinodiscophyceae & Family Biddulphiaceae & Family Chaetoceraceae \\
\hline SubClass Thalassiosirophycidae & Biddulphia tridens Ehrenberg & Chaetoceros radians Schütt \\
\hline Order Thalassiosirales & Terpsinoe musica Ehrenberg & Chaetoceros teres Cleve \\
\hline
\end{tabular}


Family Thalassiosiraceae

Thalassiosira angulata (Gregory) Hasle Thalassiosira eccentrica (Ehrenberg) Cleve

Thalassiosira leptopus (Grunow) Hasle \& G. Fryxell

Thalassiosira subtilis (Ostenfeld) Gran

Family Skeletonemataceae

Skeletonema costatum (Greville) Cleve

Family Lauderiaceae

Lauderia annulata Cleve

Lauderia compressa Peragallo

Detonula pumila (Castracane) Gran

Family Stephanodiscaceae

Cyclotella meneghiniana Kützing

Cyclotella planctonica Brunnth.

Cyclotella socialis Schütt

Cyclotella stylorum Brightwell

SubClass Coscinodiscophycidae

Order Melosirales

Family Melosiraceae

Melosira arctica (Ehrenberg) Dickie

Melosira nummuloides Agardh
Order Hemiaulales

Family Hemiaulaceae

Climacodium frauenfeldianum Grunow

Cerataulina pelagica (Cleve) Hendey

Hemiaulus membranaceus Cleve

Hemiaulus sinensis Greville

Family Bellerocheaceae

Bellerochea malleus (Brightwell) Van Heurck

Family Streptothecaceae

Helicotheca tamesis (Shrubsole) Ricard

Family Plagiogrammaceae

Dimerogramma fulvum Gregory

SubClass Lithodesmiophycidae

Order Lithodesmiales

Family Lithodesmiaceae

Ditylum brightwellii (West) Grunow

Ditylum sol Grunow

Lithodesmium undulatum Ehrenberg

SubClass Cymatosirophycidae

Order Cymatosirales

Family Cymatosiraceae
Chaetoceros tortissimus Gran

Chaetoceros sp.

Bacteriastrum delicatulum Cleve

Bacteriastrum hyalinum Lauder

Order Leptocylindrales

Family Leptocylindraceae

Leptocylindrus danicus Cleve

Leptocylindrus minimus Gran

Class Fragilariophyceae

SubClass Fragilariophycidae

Order Fragilariales

Family Fragilariaceae

Asterionellopsis glacialis (Castracane) F.E. Round

Fragilaria vitrea (Kützing) Grunow

Opephora schwartzii (Grunow) Petit

Synedra cristalina var. typica Lyngbye

Synedra longissima Smith

Synedra robusta Ralfs

Tabellaria flenestrata (Lyngbye) Kützing

Order Thalassionematales

Family Thalassionemataceae

Table1. (continued)

Thallassionema nitzschioides (Grunow)
Mereschkowsky
Order Rhabdonematales
Family Rhabdonemataceae
Rhabdonema punctatum (Harvey \& Bailey)
Stodder
Order Striatellales
Family Striatellaceae
Grammatophora oceanica (Ehrenberg) Grunow
Family Eunotiaceae
Eunotia flexuosa (Brébisson) Kützing
Class Bacillariophyceae
SubClass Bacillariophycidae
Order Lyrellales

Family Lyrellacea

Petroneis humerosa (Brébisson) Stick \& Mann

Order Achnanthales

Pleurosigma speciosum Smith

Rhoicosigma oceanicum $\mathrm{H}$. F.

Família Plagiotropidaceae

Tropidoneis elegans Smith

Tropidoneis vitrea Smith

Family Stauroneidaceae

Stauroneis sp.

Order Thalassiophysales

Familya Catenulaceae

Amphora arenaria Donk

Amphora elegans H. Peragallo

Amphora inflexa Brébisson

Amphora quadrata (Greville) Pers.

Amphiprora angustata Hendey

Amphiprora pulchra var. pulchella $\mathrm{H}$. Peragallo

Entomoneis alata Ehrenberg

Order Bacillariales

Family Bacillariaceae

Bacillaria paxillifera Hendey

(O. F. Müller)

Order Naviculales

Familya Pinnulariaceae
Cylindrotheca closterium (Ehrenberg)
Surirella sp.

Division Chlorophyta

Class Euchlorophyceae

Order Volvocales

Family Volvocaceae

Eudorina sp.

Order Chlorococcales

Family Radiococcaceae

Eutetramorus planctonica (Korch.) Bourr.

Class Zygophyceae

Order Zygnematales

Family Desmidiaceae

Bambusina brebrissonii Kützing

Closterium gracile Brébisson

Closterium johnsonii W \& G.S. West

Closterium kuetzingii Brébisson

Closterium macilentum Brébisson

Cosmarium ornatum var. pseudolagoense Förster \& Eckert

Desmidium baileyi (Ralfs) de Bary

Desmidium cylindricum Greville 
SANTANA, D. dos S. Microphytoplankton of the Marapanim estuary (Pará, Northern Brazil)

Caloneis sp.

Pinnularia sp.

Family Diploneidaceae

Diploneis bombus Ehrenberg

Diploneis crabo Ehrenberg

Diploneis splendida Gregory

Family Naviculaceae

Navicula cuspidata (Kützing) Kützing

Navicula sp.

Family Pleurosigmataceae

Gyrosigma balticum (Ehrenberg) Cleve

Pleurosigma delicatum Smith

Pleurosigma decorum Smith

Pleurosigma spencerii Smith
Reimann \& Lewin

Nitzschia insignis var. smithii Ralfs

Nitzschia longissima typica Brébisson

Nitzschia lorenziana Grunow

Nitzschia maxima Grunow

Nitzschia obtusa Smith

Nitzschia scalaris (Ehrenberg) W. Smith

Nitzschia sp.

Pseudo-nitzschia seriata (Cleve) H.Peragallo

Order Surirellales

Family Surirellaceae

Petrodictyon gemma (Ehrenberg)

Mann

Surirella elegans Ehrenberg

Surirella fastuosa Ehrenberg
Groenbladia neglecta (Raciborski) Teiling

Hyalotheca dissiliens (Smith) Brébisson

Pleurotaenium trabecula (Ehrenberg) Nägeli

Staurastrum cerastes var. pulchrum Scott \& Grönblad

Staurastrum hystrix var. brasiliense Grönblad

Staurastrum stelliferum Borge

Triploceras verticillatum Bailey

Xanthidium amazonense Scott \& Croasdale

Xanthidium canadense var. borgei Först

Xanthidium fragile Borge

Xanthidium trilobum Nordstedt

Family Zygnemataceae

Mougeotia sp.

Zygne sp.

Dinoflagellates (Dinophyta) represented $6.6 \%$ of the identified taxa. These organisms are more representative of coastal areas and may be found preferable in oceanic waters and entering in the estuaries during seasons of high salinity (dry season) which make environmental conditions favorable to their survival (Balech, 1988). For this reason only few species are reported for estuarine regions (Feitosa, 1988; Lacerda, 1994; Lacerda et al., 2004). In the present study, dinoflagellates showed remarkable importance during the dry season, principally in the stations situated in the mouth of the estuary. However, they were also sporadically observed in the inner stations and during the ebb tide.

Barros - Franca \& Batista (1991) observed the presence of Ceratium furca and Dinophysis caudata in samples of the harbour of Suape (Pernambuco, Brazil) during the flood tides and showed the importance of the currents in the transport of these species to the referred ecosystem. Maia (1995) observed the presence of ten species of dinoflagellates in the Pina Basin (Pernambuco-Brazil) from which Ceratium furca, C. fusus and C. massiliense presented considerable occurrence during the flood tides of the dry season. In Northern Brazil, previous studies performed in the surf zone of Canela Island (Bragança, Pará), showed that species of this group accounted for $10 \%$ of the local microphytoplankton (Sousa et al., 2008).

Another algae group that is common in the estuarine environment is the group of the Cyanophyta represented in the Marapanim estuary by five taxa (2.8\%). Samayda (1983) reported that blue-green algae became more important when salinity values decreased and that they were very adapted to freshwater environments. However, in the present work, the Cyanophyta just occurred during the dry season, when the highest salinity values were observed, and principally in the stations closer to the mouth of the estuary. Although this group has been reported as a freshwater species for the studied area they might be considered euryhaline species. The same observation was carried out by Koening (1997) and Koening et al. (2002), in the Ipojuca estuary (Pernambuco-Brazil) and by Sousa et al. (2008; 2009) in the Amazon littoral.

The number of identified taxa in the present study was higher than that registered by other authors in different ecosystems of Pará state (Amazon region, north Brazil) in which it was observed lower specific diversity than that found in the Marapanim estuary (Paiva, 1991; Sousa et al., 2008, 2009). However, in these studies as it could be seen in a previous study developed in the Marapanim estuary, the diatoms were the group most represented.

For the ecological frame of the identified taxa four categories were established: planktonic oceanic, planktonic neritic, tychoplanktonic and freshwater species (Figure 1). In the Marapanim estuary planktonic neritic species were dominant $(33.1 \%)$, followed by neritic littoral (tychoplanktonic-30.9\%) and planktonic oceanic species (21.5\%). In the 
studied area, as it could be observed for other Brazilian estuaries, the planktonic oceanic and planktonic neritic species were predominant and species such as Coscinodiscus apiculatus, C. centralis, Chaetoceros atlanticus, C. peruvianus, C. lorenzianus, C. curvisetus, Odontella regia, Skeletonema costatum and Thalassiosira spp. were the most commonly represented (Kutner, 1972; Silva - Cunha \& Almeida, 1987/89; Sassi, 1991; Moura, 1992; Lacerda et al., 2004). The fact that the tychoplanktonic species were ranked second in number of identified taxa might be associated to the force of tide currents and the shallowness of the estuary which are responsible for sediment resuspension and the presence of benthic and epiphyte species in the plankton. Hendey (1964) also observed that many neritic littoral (tychoplanktonic) species could be maintained in the water column during a large part of their life cycle when removed from their natural environment. For this reason they could be frequently sampled in plankton net hauls.

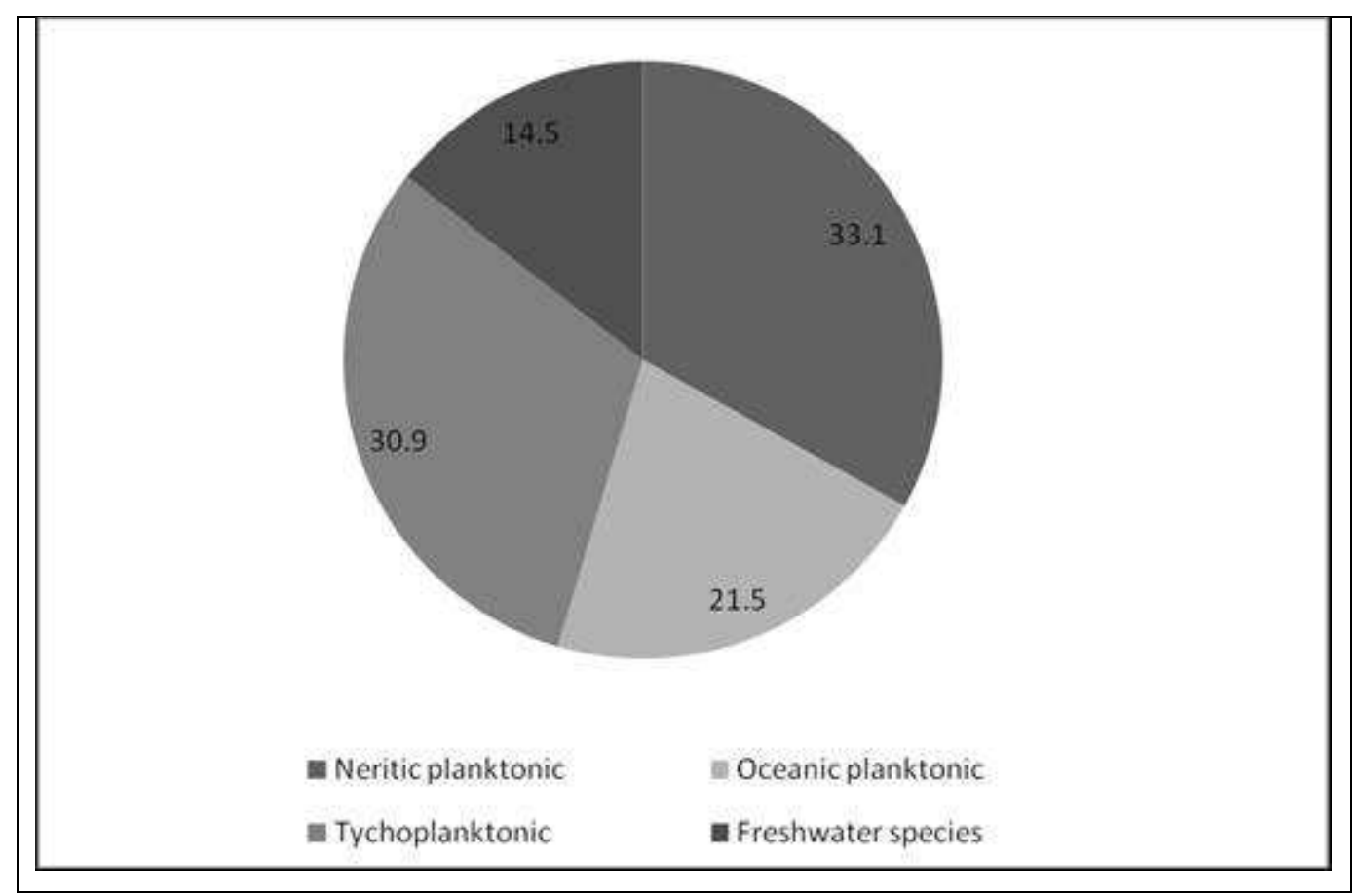

Figure 1: Ecological categories representation (\%) of the different species registered in the Marapanim estuary (November/2002 to September/2003).

Bustillos - Gusmán (1986) verified that in three different rich organic matter mangrove ecosystems in La Paz bay (Mexico), which also presented high levels of sedimentation, benthic diatoms and epiphytes were more adapted to the environment and Amphora and Pleurosigma were the predominant genera. Schreiber \& Pennock (1995) also reported the importance of benthic microalgae in the primary production of shallow waters of Weeks Bay estuary (Alabama). These studies, and other performed in the Amazon coast (Sousa et al., 2008; 2009), showed that the introduction of benthic and epiphyte species in the plankton is very common in estuarine zones despite being tropical or subtropical regions and that these organisms contributed to the enrichment of the species' inventory and their high primary production.

The presence of oceanic and neritic species must be attributed to tidal currents and as it was observed by Frenguelli (1928) it is difficult to establish exact boundaries between neritic and oceanic forms because many species may be found in the ocean or next to coastal regions due to their ecological ability to colonize marine and estuarine environments. Guillard and Rilham (1977) also suggested the inclusion of the term "type species" for the characterization of planktonic populations. They referred to Skeletonema costatum, Leptocilyndrus danicus, Chaetoceros curvisetus and C. didymus as coastal forms of the setentrional Atlantic, while Rhizosolenia imbricata would characterize the oceanic plankton. Frenguelli (1928) also considered this last species as characteristic of the Atlantic Ocean.

Silva - Cunha \& Eskinazi - Leça (1990), discussed that for the determination of the "type species" methodical studies in different sample stations and seasonal periods are 
SANTANA, D. dos S. Microphytoplankton of the Marapanim estuary (Pará, Northern Brazil)

necessary. The distribution of sample stations in the Marapanim River were limited to the estuarine region and although different seasonal periods were sampled in the present study (November/2002 - dry season; March/2003 - rainy season; July/2003 beginning of the rainy/dry transition season; and September/2003 - dry season), it was not possible to characterize "type species". For this reason it was more appropriate to use the terms oceanic planktonic, neritic oceanic, ticoplanktonic and freshwater species as was commonly used by Gomes (1989), Silva-Cunha \& Eskinazi-Leça (1990) and other to designate species whose habitats are in oceanic or coastal environments.

In the present study 18 new occurrences were reported for Pará state which are: Amphiprora angustata, A. pulchra var. pulchella, Amphora elegans, A. inflexa, A. quadrata, Ceratium lineatum, C. teres, Chaetoceros eibenii, C. furcellatus, C. radians, C. tortissimus, Cocconeis fluminensis, Cyclotella planctonica, C. socialis, Cymatosira belgica, Diploneis splendida, Fragilaria vitrea and Gymnodinium splendens; showing its relevance for the knowledge of planktonic communities composition of estuaries from the Amazon region.

\section{ACKNOWLEDGMENTS}

This work was supported in part by CAPES (MEC, Brazil) through the concession of a Postgraduate fellowship to Daniela dos Santos Santana and by grant MilênioNEC/CNPq/MCT. The authors Dr. Luci Cajueiro Carneiro Pereira and Dr. Rauquírio Marinho da Costa would like to thank CNPq (Brazil) for their research grants (\# 304392/2005-7 and \# 308953/2006-1, respectively).

\section{LITERATURE CITED}

BALECH, E. 1988. Los Dinoflagelados del Atlantico Sudoccidental. Pub. Espec. Inst. Esp. Oceanogr. n. 1, Espanha. 310pp.

BARROS-FRANCA, L.M. de.; BATISTA, R.N. 1991. Distribuição Horizontal e Abundância Relativa do Fitoplâncton no Complexo Estuarino Lagunar do Suape. In: Encontro Brasileiro de Plâncton, 4. Anais do Encontro Brasileiro de Plâncton. Univ. Fed. PE., Recife, Pernambuco. p. 99-115.

BERREDO, J.F.; VILHENA, M.P.S.P. 2002. Geoquímica do Selênio, mercúrio, arsênio e outros metais ( $\mathrm{Cd}, \mathrm{Pb}, \mathrm{U}$ ) de impacto ambiental em sedimentos quaternários da amazônia brasileira. Relatório parcial. Setembro.

BOURRELY, P. 1972. Les algues d'eau douce: initiation a la systematique. Paris: N. Bounder, v.1: les algues vertes. 472pp.

BRANDINI, F.P.; LOPES, R. M.; GUTSEIT, K. S.; SPACH, H.L.; SASSI, R. 1997 Planctologia na Plataforma Continental do Brasil. Diagnose e Revisão Bibliográfica. REVISEE. Belém-PA.

BUSTILLOS-GUSMÁN, J.J. 1986. Fitoplâncton en tres ecosistemas de manglar de la Bahia de la Paz, B.C.S. (México) I. Diatomeas. Anales del Instituto de Ciências del Mar y Limnologia, 13(3): 301-306.

CLEVE-EULER, A. 1951. Die diatomeen von schweden und Finland. Kungl. Svenka Vet. Handlinger. Stockholm, fjarde ser. 2, n. 1, 163pp.

CLEVE-EULER, A. 1952. Die diatomeen von schweden und Finland. Kungl. Svenka Vet. Handlinger. Stockholm, fjarde. ser. 3, n. 3, 153pp.

CLEVE-EULER, A. 1953. Die diatomeen von schweden und Finland. Kungl. Svenka Vet. Handlinger. Stockholm, fjarde ser. 4, n. 1, 255pp.

COSTA NETO, S.V.; SENNA, C.; LOBATO, L.C. 2000. Estrutura e diversidade de bosques de manguezal da Baía de Marapanim, Pará, Brasil. Conferência Internacional sobre Estuários e Manguezais, 1 (Mangrove 2000). Recife.PE. CD-ROOM.

CUPP, E.D. 1943. Marine plankton diatoms of the West Coast of North America. Bulletin of the Scripps Institution of Oceanography of the University of the California, 5: 1-238.

DESIKACHARY, T.S. 1959. Cyanophyta. New Delhi. Indian. Council of Agricultura Researcher. 686 p. 
DODGE, J.D. 1982. Marine Dinoflagellates of the Isle. Her Majestty's Stationery Office. London, 303 p.

ESKINAZI-LEÇA, E. 1967/69. Shelf off Alagoas and Sergipe (Northeastern Brazil). 3. Diatoms from the São Francisco River Mouth.Trab. Oceanogr. Univ. Fed. PE., 9/11: 181192.

ESKINAZI-LEÇA, E.; Barros-Franca, L.M.; Macêdo, S.J. 1984. Estudo Ecológico da Área de Itamaracá (Pernambuco - Brasil). XXIV "Standing Stock" do Fitoplâncton do Estuário do Rio Botafogo, durante Janeiro a Dezembro/1975. Trab. Oceanogr. Univ. Fed. PE., 18: 153-192.

ESKINAZI-LEÇA, E.; KOENING, M.L. 1985/86. Distribuição das Diatomáceas (Bacillariophyceae) na Área de Suape (Pernambuco - Brasil). Trab. Oceanogr. Univ. Fed. $P E ., 19: 73-100$.

ESPÍRITO SANTO, R.; ISAAC, V. J. 1999. Alimentação e aspectos da reprodução da uricica Cathorops spixii (Agassiz, 1829) (Osteychthyes, Siluriformes, Ariidae), no estuário do Rio Caeté (Município de Bragança-PA). Boletim do Museu Paraense Emílio Goeldi. Série Zoologia, 15 (1): 95-111.

FEITOSA, F.A.N. 1988. Produção primária do fitoplâncton correlacionada com parâmetros bióticos e abióticos na Bacia do Pina. (Recife-Pernambuco, Brasil). Master's Thesis, Universidade Federal de Pernambuco, Recife, Pernambuco. 270pp.

FLORES - MONTES, M. 1996. Variação Nictemeral do Fitoplâncton e Parâmetros Hidrológicos no Canal de Santa Cruz (Itamaracá - PE). Master's Thesis, Universidade Federal de Pernambuco, Recife, Pernambuco. 163pp.

FRENGUELLI, J. 1928. Diatomeas del Oceano Atlantico. Anais do Museo Nacional Historia Naturale Bernardino Rivadavia, Buenos Aires, 34: 497 - 572.

GLASER, M.; DIELE, K. 2004. Asymmetric outcomes: assessing central aspects of the biological, economic and social sustainability of a mangrove crab fishery, Ucides cordatus (Ocypodidae), in north Brazil. Ecological Economics, 49: 361-373.

Gomes, N.A. 1989. Composição e Variação Anual do Fitoplâncton na Plataforma Continental de Pernambuco. Master's Thesis, Universidade Federal de Pernambuco, Recife, Pernambuco. 198pp.

GUILLARD, R.R.; RILHAM, P. 1977. The ecology of marine planktonic diatoms. In: Werner, D. (Ed). The Biology of Diatoms, Oxford, Black - well Scientific Publications. p. $372-469$.

HENDEY, N.I. 1964. An Introductory of the Smaller Algae of British Coastal Waters. Part 5: Bacillariophyceae (Diatoms). Fishery Investigations. Série 4. 317pp.

HUSTEDT, F. 1930. Die Kieselalgen. Deutschlands, Osterreichs und der Schweiz. In: Rabenhorst, L. (Ed). Kryptogamen-flora von Deustschland, Osterreich un der Schweiz. Akademische Verlagsgesellschaft, Geest, Portigh. v. 7. 920pp.

HUSTEDT, F. 1959. Die Kieselalgen. Deutschlands, Osterreichs und der Schweiz. In: Rabenhorst, L. (Ed). Kryptogamen-flora von Deustschland, Osterreich un der Schweiz. Akademische Verlagsgesellschaft, Geest, Portigh. v. 7. 845pp.

HUSTEDT, F. 1961/1966. Die Kieselalgen. Deutschlands, Osterreichs und der Schweiz. In: Rabenhorst, L. (Ed). Kryptogamen-flora von Deustschland, Osterreich un der Schweiz. Akademische Verlagsgesellschaft, Geest, Portigh. v. 7. 816pp.

JOIEUX, J.; Pereira, B.B.; Almeida, H.G. 2004. The flood-tide ichthyoplanktonic community at the entrance into a Brazilian tropical estuary. Journal of Plankton Research, 26 (2): 12771287.

KJERFVE, B.; Lacerda, L.D., Diops, S. 1997. Mangrove ecosystem studies in latin America and Africa. UNESCO, Paris. 349pp.

KOENING, M.L. 1997. Ecologia e Dinâmica do Fitoplâncton no Estuário do Rio Ipojuca após a Implantação do Porto de Suape (Pernambuco - Brasil). PhD Thesis, Universidade Federal de Pernambuco, Recife, Pernambuco. 263pp. 
SANTANA, D. dos S. Microphytoplankton of the Marapanim estuary (Pará, Northern Brazil)

KOENING, M.L.; ESKINAZI-LEÇA, E.; Neumann-Leitão, S.; Macedo, S.J. 2002. Impactos da Construção do Porto de Suape sobre a Comunidade Fitoplanctônica do Estuário do rio Ipojuca (Pernambuco - Brasil). Acta Bot. Bras., 16(4): 407-420.

KREMER, K.I.; BROCKMANN, U.H.; WARWICK, R. M. 1994. Tidal Estuaries. Manual of Sampling and Analytical Procedures. Rotterdam: A. A. Balkema. 304pp.

KRUMME, U.; LING, T. 2004. Tidal-induced changes in a copepod-dominated zooplankton community in a macrotidal mangrove Channel in northern Brazil. Zoological Studies, 43(2): 404-414.

KUTNER, M.B.B. 1972. Variação Estacional e Distribuição do Fitoplâncton na Região de Cananéia. PhD Thesis, USP, São Paulo, São Paulo. 104pp.

LACERDA, S.R. 1994. Variação Diurna e Sazonal do Fitoplâncton do Estuário do Rio Paripe (Itamaracá - Pernambuco - Brasil). Universidade Federal de Pernambuco, Recife, Pernambuco. 142pp.

LACERDA, S.R.; KOENING, M.L.; LEITÃO, S.N.; MONTES, M.J.F. 2004. Phytoplankton Nyctemeral Variation at a Tropical River Estuary (Itamaracá- Pernambuco- Brazil). Brazilian Journal of Biology, 64(1):81-94.

MAIA, P.R. 1995. Composição e Densidade Fitoplanctônica na Bacia do Pina, Recife Pernambuco. Master's Thesis, Universidade Federal de Pernambuco, Recife, Pernambuco. 135pp.

MARTORANO, L.G., FERREIRA, L.C., CÉSAR, E.G.M; PEREIRA, I.C.B. 1993. Estudos Climáticos do Estado do Pará, Classificação Climática (KOPPEN) e Deficiência Hídrica (THORNTH, WHITE, MATHER). Belém: SUDAM/EMBRAPA, SNLCS. 1-53.

MELO, N.F.A.C.; PAIVA, R.S.; SILVA, M.M.T.da. 2006. Variação diurnal da densidade planctônica na região intertidal da praia de Ajuruteua (Bragança-Pará). Boletim do Museu Paraense Emílio Goeldi, Série Ciências Naturais, 1(2): 153-180.

MOREIRA - FILHO, H. 1961. Diatomáceas da Baía de Guaratuba (Paraná - Brasil) (Chrysophyta - Bacillariophyceae). Bol. Univ. do Paraná. Botânica, 3: 1-35.

MOREIRA - FILHO, H.; MARUO, Y.; VALENTE - MOREIRA, I.M.; ESKINAZI - LEÇA, E. 1968. Diatomáceas da Lagoa Olho d'água (Estado de Pernambuco - Brasil) (Chrysophyta Bacillariophyceae). Bol. Univ. Paran, Botânica. 21: 1-17.

MOREIRA - FILHO, H.; VALIELA - MOREIRA, I.M.; MOSIMANN, R.M.S. 1985. Catálogo das Diatomáceas (Chrysophyta - Bacillariophyceae) Marinhas e Estuarinas do Estado de Santa Catarina, Brasil. Ínsula, 15: 33-88.

MOREIRA - FILHO, H.; VALIELA - MOREIRA, I.M.; MOSIMANN, R.M.S.; CUNHA, J.A. 1990. Avaliação Florística e Ecológica das Diatomáceas (Chrysophyta - Bacillariophyceae) Marinhas e Estuarinas do Estado do Paraná, Santa Catarina e Rio Grande do Sul. Est. Biol., 25: 05-48.

MOREIRA - FILHO, H.; ESKINAZI - LEÇA, E.; VALENTE - MOREIRA, I.M.; CUNHA, J.A. 1999. Avaliação Taxonômica e Ecológica das Diatomáceas (Chrysophyta Bacillariophyceae) Marinhas e Estuarinas nos Estados de Pernambuco, Paraíba, Rio Grande do Norte, Ceará, Piauí, Maranhão, Pará e Amapá, Brasil. Trab. Oceanogr.Univ. Fed. PE., 27(1): 55-90.

MOSIMANN, R.M.S. 1985. Contribuição ao conhecimento das diatomáceas (Chrysophyta Bacillariophyceae) da Baía Norte - Florianópolis - Santa Catarina - Brasil. Ínsula, 15: 3-32.

MOSIMANN, R.M.S. 1988. Estudo Preliminar das Diatomáceas (Chrysophyta Bacillariophyceae) da Baía Sul, Florianópolis, Santa Catarina - Brasil. Ínsula, 18: 23-74.

MOURA, G.F. de. 1992. Comportamento Diurno e Sazonal de Parâmetros Fitoplanctônicos e Hidrológicos no Estuário do Rio Paraíba do Norte, Estado da Paraíba, Brasil. Master's Thesis, Universidade Federal de Pernambuco, Recife, Pernambuco. 206pp.

PAIVA, R.S. 1991. Composição e Biomassa do Fitoplâncton da Baía do Guajará (Pará Brasil). Master's Thesis, Universidade Federal de Pernambuco, Recife, Pernambuco. 195pp. 
PATRICK, R. 1967. Diatoms Communities in Estuaries. In: Lauff, G. H. (Ed). Estuaries. Washinghton: AAAS. 311-315pp.

PÉRAGALLO, H.; PÉRAGALLO, M. 1897-1908. Diatommées marines de France et des districts marítimes voisins. Paris. M. J. Tempére. 491pp.

RIBEIRO, S.M.M.S. 1996. Caracterização taxonômica e ecológica das comunidades pico-, nano-e microplânctônicas, superficial e profunda, da zona eufótica do Atlântico Sul. PhD Thesis, .USP, São Paulo, São Paulo. 155 pp.

ROUND, F.E.; CRAWFORD. R.M.; MANN, D.G. 1990. The Diatoms, Biology \& Morphology of the Genera. Cambridge University. Cambridge. 747 pp.

SANTANA, D.S. 2004. Composião Florística e Variação Espaço-Temporal dos Parâmetros Ambientais e da Biomassa Fitoplanctônica do Estuário do Rio Marapanim (Pará, Brasil). Master's Thesis, Universidade Federal do Pará, Bragança, Pará. 113pp.

SARDEIRO, M.S.; ESKINAZI - LEÇA, E. 1985. Distribuição das Diatomáceas (Bacillariophyceae) na Platafoema Continental dos Estados de Alagoas e Sergipe (Brasil). Anais da VIII Reunião Nordestina de Botânica. 33-56p.

SASSI, R. 1991. Phytoplankton and Environmental Factors in the Paraíba do Norte River Estuary, Northeastern Brazil: Composition, Distribution and quantitative Remarks. Boletim Instituto Oceanográfico da Universidade de São Paulo, 39(2):93-115.

SCHREIBER, R.A.; PENNOCK, J.R. 1995. The Relative Contribution of Benthic Microalgae to Total Microalgal Production in a Shallow Sub-tidal Estuarine Environmetal. Ophelia, 42:335352.

SILVA, C.A.; MENDES, A.C. 2001. Aspectos morológicos da planície estuarina do rio Marapanim-Pará. Anais do $8^{\circ}$ Congresso da Associção Brasileira de Estudos do Quaternário. Imbés, RS. Boletim de resumos- CD-Rom.

SILVA, C.A.; SOUZA-FILHO, P.W.; RODRIGUES, S.W P. 2009. Morphology and modern sedimentary deposits of the macrotidal Marapanim Estuary (Amazon, Brazil). Continental Shelf Research, 29: 619-631.

SILVA-CUNHA, M. DA G.G. DA, ALMEIDA, C.D.P. de. 1987/89. Taxonomia e Ecologia do Microfitoplâncton do Estuário do Rio Timbó (Pernambuco - Brasil). Trab. Oceanogr. Univ. Fed. PE., $20: 35-52$.

SILVA-CUNHA, M. DA G.G.; ESKINAZI-LEÇA, E. 1990. Catálogo das Diatomáceas (Bacillariophyceae) da Plataforma continental de Pernambuco. Recife. SUDENE/UFPE. 318pp.

SILVA-CUNHA, M.DA G.G. DA; NEUMANN-LEITÃO, S. 1993. Abordagem ecológica da Ficoflora Planctônica em Áreas Estuarinas do estado de Pernambuco - Brasil. In: Congresso Latinoamericano [de] Ficologia, 3., Reunión Iberoamericano [de] Ficologia, 1., México. D.F.: Sociedad Ficologica de America Latina y el Caribe: Sociedad Ficologica de México: Sociedad Española de Ficologia. 123p.

SMAYDA, T.J. 1983. The Plankton of Estuaries. In: Ketchum, B.H. (ed.) Estuaries and Enclosed Seas. Amsterdan: Elsevier, (4): 65-112p.

SOURNIA, A. 1986. Atlas du phytoplancton marin. Vol. 1. Introduction, Cyanophycées, Dictyochophycées, Dinophycées et Rhaphidophycées. Editions du Centre National de la Recherche Scientifique. Paris. 219pp.

SOUSA, E.B.; COSTA, V.B.; PEREIRA, L.C.C.; COSTA, R.M. da. 2008. Microfitoplâncton de águas costeiras amazônicas: Ilha Canela (Bragança, PA, Brasil). Acta Bot. Bras., 22(3): 626-636. 2008.

SOUSA, E.B.; COSTA, V.B.; PEREIRA, L.C.C.; COSTA, R.M. da. Variação temporal do fitoplâncton e dos parâmetros hidrológicos da zona de arrebentação da Ilha Canela (Bragança-Pará-Brasil). Acta Bot. Bras., 23(4): 1084-1095. 2009.

SUDAM. 1994. Atlas Climatológico da Amazônia Brasileira. SUDAM/PHCA. Belém. 125pp.

TOMAS.C.R. 1997. Identifying Marine Phytoplankton. Academic Press, Inc. 858pp. 
TRAVASSOS, P.E.P.F. 1991. Hidrologia e Biomassa Primária do Fitoplâncton do estuário do Rio Capibaribe, Recife - Pernambuco. Master's Thesis, Universidade Federal de Pernambuco, Recife, Pernambuco. 288pp.

XIE, P.; YANG, Y. 2000. Long-term changes of Copepoda community (1957-1996) in a subtropical Chinese lake stocked densely with planktivorous filter-feeding silver and bighead carp. Journal of Plankton Research, 22: 1757-1778.

WOOD, E. J. F. 1968. A phytoplankton study of the Amazon region. Bull Marine Sc., 16(1): 102-123. 